\title{
De Lévi-Strauss \\ aos índios na universidade \\ Entrevista com Manuela Carneiro da Cunha
}

\author{
Edson Tosta Matarezio Filho ${ }^{1}$ \\ Universidade de São Paulo
}

Este depoimento concedido pela professora Manuela Carneiro da Cunha é uma aula sobre boa parte da vida e obra de Claude Lévi-Strauss. A entrevista aconteceu no âmbito da produção do filme documentário O que Lévi-Strauss deve aos Ameríndios ${ }^{2}$, que contou também com diversos outros especialistas na obra do mestre francês. Encontramos Manuela na manhã do dia 15 de março de 2013 e fizemos as filmagens na sala da sua casa, defronte ao seu jardim de bonsais.

A influência de Lévi-Strauss na obra de Manuela é evidente e sua filiação ao estruturalismo é declarada. Seu primeiro artigo, "Lógica do mito e da ação: o movimento messiânico canela de 1963", publicado originalmente na revista L'Homme (1973), é considerado pela autora "uma extensão da teoria estrutural" (Carneiro da Cunha, 2010: 379). Não bastasse isso, a antropóloga estudou pessoalmente com o fundador do estruturalismo na antropologia, assistindo aos seus seminários nos anos 1960. O encontro, tanto pessoal como com a obra de Lévi-Strauss, a converteu das ciências exatas para as humanidades. "Apresentei-me como sendo do Brasil, o que visivelmente não o impressionou. Tentei então outra via, e disse-lhe que era formada em matemática pura. Foi quando ele ficou realmente interessado" (idem: 378).

Nesta entrevista, Manuela nos apresenta um panorama de como eram os estudos da América do Sul indígena antes de Lévi-Strauss. Principalmente, nos mostra o quanto os estudos do antropólogo francês motivaram e influenciaram as gerações de pesquisadores que o sucederam. Termos e oposições difíceis de se compreender no jargão estruturalista são elucidados por Manuela, como estrutura ou as oposições entre universais e etnografia, ciência moderna e ciência do concreto, conceitos e perceptos, dentre outros. 
Após esta magnífica aula sobre Lévi-Strauss, a entrevista envereda para considerações sobre o crescente número de indígenas que estão entrando na universidade, para fazer os mais diversos cursos, inclusive de antropologia. O contato destes indígenas com o estudo da antropologia indicaria um pensamento novo por vir? Quais os paradoxos envolvidos na formação de professores indígenas? $\mathrm{O}$ que acontece quando os próprios indígenas começam a reivindicar "um papel central na interpretação das suas próprias sociedades"? "Certamente eles vão fazer muitas críticas à antropologia". Estas são algumas questões exploradas nesta conversa, em conexão com as pesquisas mais atuais de Manuela. Professora aposentada do Departamento de Antropologia da Universidade de São Paulo e da Universidade de Chicago, atualmente seu foco de estudos é a formação de redes de pesquisa intercultural envolvendo populações tradicionais e cientistas. Trata-se de propor um novo modelo de pesquisa científica que fortaleça a produção local de conhecimentos.

O que a senhora considera que Lévi-Strauss trouxe de novo para o conbecimento sobre os indios?

Foi por acaso, por causa de um convite inesperado, que Lévi-Strauss veio para o Brasil na década de 1930. Mas, dentre os vários professores que também vieram na mesma época, a da fundação da USP, ele foi o que se interessou em estudar os índios brasileiros, as sociedades indígenas brasileiras.

Parece-me significativo que se tenha interessado não só pelo que se poderia hoje chamar o patrimônio imaterial das sociedades indígenas, suas formas de pensamento, mas também que o fez através de coisas como a arte - por exemplo as pinturas caduveu -, os conhecimentos sobre plantas e a tecnologia.

$\mathrm{Na}$ época, dizia-se que o continente americano era o menos conhecido etnograficamente. Houve, desde o século XIX, sobretudo, muitos alemães, austríacos, russos, ingleses, que eram a um tempo naturalistas, viajantes, exploradores e etnógrafos. Em geral pessoas como [Carl Friedrich Philipp] Von Martius, que era um eminente botânico, mas ao mesmo tempo eram cronistas de viagens e que trouxeram muita informação. Havia também pessoas como [Karl] Von Den Steinen, que foi o primeiro a descrever as sociedades do alto Xingu. Enfim, tudo isso configurava certa riqueza de informação, mas também muito dispersa, muito mal conhecida e, sobretudo, muito incompleta.

$\mathrm{Na}$ época em que Lévi-Strauss veio para cá houve um grande salto, devido a um etnólogo alemão autodidata, [Curt] Nimuendajú. Este último fez os primeiros estudos de 
longa duração de várias sociedades indígenas, entre elas várias sociedades jê do Brasil Central, e também outras sociedades, como os Ticuna. A contribuição de Nimuendajú é imensa. Ficou muito pouco reconhecida no Brasil até que [Robert] Lowie, um antropólogo americano de Berkeley que organizou o Handbook of South American Indians, o traduziu. Não só traduziu, mas até organizou os papéis de Nimuendajú e traduziu para inglês os livros principais dele. Os Timbira [Orientais], por exemplo, foi publicado por ele, em inglês, em 1946. Até hoje Os Timbira Orientais, até onde eu sei, não foram publicados em português. A contribuição de Nimuendajú é absolutamente essencial.

Isso é ligeiramente posterior à chegada de Lévi-Strauss aqui. Não que os estudos de Nimuendaju não tivessem já sido feitos, mas só ficaram realmente bem conhecidos depois. Durante a Segunda Guerra Mundial, Lévi-Strauss tenta voltar [ao Brasil] e não consegue, numa época em que Getúlio [Vargas] não está absolutamente disposto a acolher judeus, como, aliás, os Estados Unidos. Ele narra todos esses episódios em Tristes Trópicos. E quem quiser saber de detalhes, pode e deve recorrer ao livro recém-saído de Emanuelle Loyer (2015), a biografia de Lévi-Strauss, que eu acabo de receber e ainda não li.

Consta que Lévi-Strauss era bastante reservado, mas que a primeira mulher dele, Dina, que era folclorista, se tornou muito amiga de Mário de Andrade. Ele tinha uma formação de filosofia, que é uma tradição muito forte na França na formação de antropólogos e de sociólogos: toda a escola durkheimiana, por exemplo, era originalmente de filósofos. Essa tradição filosófica na antropologia francesa continua até hoje muito forte, [Philippe] Descola é um exemplo, e vários outros. Essa é uma característica também importante de Lévi-Strauss. O projeto dele quando começa a trabalhar aqui - primeiro nas férias da Universidade de São Paulo - e depois, quando ele larga a Universidade, e vai fazer uma grande expedição, ele vai como filósofo. Ele diz no livro Tristes Trópicos que filosofia não deve ser feita olhando para o próprio umbigo e sim saindo pelo mundo para ter uma ideia de como a humanidade pensa. É aparentemente paradoxal, se lembrarmos que ele deve muito a Kant, talvez o mais recluso e mais chegado ao próprio umbigo dos filósofos. Isso é absolutamente central em Lévi-Strauss. Ele estava com problemas filosóficos e com uma formação filosófica, ou seja, ele queria saber como funciona o pensamento humano. Esse é o lado que se costuma chamar de interesse pelo universal, mas ao mesmo tempo Lévi-Strauss fazia isso de um modo muito original. O que eu estou querendo dizer é que nem o acaso, nem o contato com sociedades indígenas no Brasil são suficientes para explicar a antropologia de Lévi-Strauss. 
Malinowski, por exemplo, também foi forçado pelas circunstâncias a fazer pesquisa de campo. Era isso ou ficar preso na Austrália, então ele preferiu ir para Melanésia. Mas Malinowski não tinha nada de filósofo. Os problemas que ele coloca não são problemas filosóficos, nem de longe nem de perto, são, no fundo, algo perto da psicologia... Enfim, não há um forte aparato teórico em Malinowski, mas uma coisa sensacional que é uma descrição de longo prazo, amiúde, a fundo, de como vive uma sociedade, como viviam, na época, os trobriandeses. Lévi-Strauss parte de um programa completamente diferente. O grande modelo dele é [Michel de] Montaigne, como ele, aliás, acaba confessando em História de Lince, que termina evocando Montaigne. Nos anos 90, quando saiu História de Lince, entrevistei Lévi-Strauss, e quando lhe perguntei à queima-roupa se o Montaigne do livro era ele próprio, ele concordou.

Eu gostaria que a senhora comentasse também a importância de Lévi-Strauss para além do americanismo.

Lévi-Strauss introduz uma enorme diferença nos estudos americanistas. Como eu disse, Nimuendajú é uma mina de etnografia, um grande etnógrafo, mas é um exemplo isolado. Era Nimuendajú e praticamente muito pouca gente em volta. Mas Lévi-Strauss não traz só uma inovação na área da etnologia ameríndia, ele traz uma enorme inovação teórica, as duas coisas não podem ser dissociadas. Digamos que a importância de Lévi-Strauss não é simplesmente a de um americanista, isso salta aos olhos. Ele foi o maior antropólogo de seu tempo: como disse certa vez Stephen Hugh-Jones, o "maior antropólogo, ponto". A gente não deve reduzi-lo ao americanismo. Por outro lado, ele deu um impulso extraordinário e são sobretudo os franceses e, em seguida, os brasileiros, que dão certa continuidade a esse fascínio pela etnografia amazônica, em grande parte devido à influência dele. Uma enorme influência sobretudo nos anos 1960, 1970 e depois com menos vigor. Mas certamente várias gerações de antropólogos importantes, pessoas como [Pierre] Clastres, [Jacques] Lizot, mais adiante o próprio Descola, Anne-Christine Taylor, são gerações e gerações. Bruce Albert, que escreveu um livro absolutamente magnífico junto com Davi Yanomami [Kopenawa e Albert, 2015], e que graças a Deus apareceu em português na tradução de Beatriz Perrone-Moisés. Então há uma tradição francesa que vem do Lévi-Strauss. 
A partir dos estudos de Lévi-Strauss, então, as descrições etnográficas na América do Sul ganham um impulso?

Até então a França tinha estudos sobre a América do Sul, mas eram, sobretudo, estudos linguísticos como os do Paul Rivet - que foram muito importantes. Isso foi antes da Segunda Guerra Mundial também e, em muitos casos, eram missionários que forneciam informações. Por exemplo, aqui no Brasil, no [Rio] Juruá, Rivet recorreu a um missionário. Tudo bem, eu não tenho nada contra missionários - nesse caso era um missionário espiritano, até muito interessante, muito bem informado, [Constant] Tastevin -, mas que não era um etnógrafo no sentido mais contemporâneo.

Realmente, Lévi-Strauss faz toda a diferença naquele momento e influencia mais de uma geração de franceses antropólogos que contribuem para a etnografia do Brasil e também influencia, via [Edmund] Leach, Stephen Hugh-Jones na Inglaterra para fazer o trabalho dele na Colômbia, entre os Barasana. Há um lado engraçado que é o seguinte: Lévi-Strauss acha que Leach nunca o entendeu e eu concordo com Lévi-Strauss. Mas, ao mesmo tempo, Stephen Hugh-Jones e a mulher dele, Christine Hugh-Jones, fizeram duas monografias espetaculares sobre os Barasana na Colômbia, que pertencem àquele complexo da bacia do Alto Rio Negro, só que do lado colombiano. Então há também uma geração inglesa nessa história. Estou falando do americanismo em geral. Os brasileiros, talvez pelo viés político que sempre houve entre acadêmicos brasileiros, e isso eu acho que é uma grande virtude, talvez tenham produzido menos etnografia que poderiam ter feito. Por exemplo, qual era o projeto do Roberto Cardoso de Oliveira? Agora estamos falando já da década de 1960. Era um projeto que não tinha nada a ver com Lévi-Strauss, era um projeto de "fricção interétnica", queria ver como as frentes pastoris e outras frentes agrícolas tinham impactado as populações indígenas. São as primeiras teses de [Júlio César] Melatti, de Roque Laraia, de toda essa turma que foi orientada por Roberto Cardoso de Oliveira.

Uma coisa interessante é a chegada de um inglês, David Maybury-Lewis. Curiosamente, ele se formou como etnólogo aqui, com influência de gente como [Herbert] Baldus, no Museu Paulista. Ele depois vai pra Harvard e propõe para Roberto Cardoso de Oliveira um projeto conjunto, Harvard Central Brazil [Project], e aí a influência de Lévi-Strauss é diretamente um desafio. É preciso lembrar que Lévi-Strauss e David Maybury-Lewis tiveram uma controvérsia que começa mais ou menos assim: David Maybury-Lewis diz que esse negócio de dualismo, que Lévi-Strauss publicou sobre 
as organizações dualistas no Brasil Central, confundia tudo, botava no mesmo saco uma ideologia que não se refletia necessariamente nas práticas sociais e encaixava toda a sorte de fenômenos na ideia de dualismo. E Lévi-Strauss responde, muito acerbamente, aliás: “a estrutura, à maneira empirista inglesa, acha que está tudo na superfície, está tudo nas práticas sociais, nas regras sociais". $\mathrm{Na}$ realidade a estrutura não está nesse plano, do empírico, a estrutura é um modelo subjacente e esse modelo pode se expressar de várias maneiras, em vários níveis e não necessariamente explicitamente nas relações sociais. Maybury-Lewis, quando faz o seu projeto Harvard Central Brazil, está decidido a demolir Lévi-Strauss. Ele alista vários jovens antropólogos, tanto americanos quanto brasileiros, para fazerem um novo estudo daquelas sociedades que o Nimuendajú tinha estudado e que eram a base empírica dos artigos sobre dualismo do Lévi-Strauss. De certa forma, pela negativa, David Maybury-Lewis está influenciado pelo Lévi-Strauss, tentando infirmá-lo.

Lévi-Strauss me parece inescapável para os americanistas, mas comportando uma série de divergências também.

A influência dele é "incontornável", como gostam de dizer os franceses, e aí acaba sendo curioso porque ele próprio tem contestadores dentro das suas fileiras. David Maybury-Lewis, por exemplo, de quem já falei. Por sua vez, Terry Turner, que trabalhou entre os Caiapó, discorda totalmente da interpretação, da abordagem teórica de David Maybury-Lewis. Os pesquisadores desse projeto [Harvard Central Brazil incluíam o Roberto DaMatta, o Melatti, várias outras pessoas daqui e várias pessoas de lá [dos EUA], não só o Terry Turner, mas a Jean Lave, que é uma super antropóloga, muito interessante. Gente como, mais tarde também, o Jon Christopher Crocker, que trabalhou com os Bororo. Cada um escreveu sua tese. Mas quando, depois de décadas, sai finalmente o volume coletivo Dialectical Societies [Maybury-Lewis ed., 1971], ele vem com uma introdução de David Maybury-Lewis - que era o chefe do projeto, supostamente, e por outro lado, acaba com um longo texto de Terry Turner fazendo um posfácio contrário às teses da introdução. É a coisa mais estranha, você tem duas visões que são completamente diferentes, o que não quer dizer que Turner espose a visão de Lévi-Strauss, muito pelo contrário.

Todos esses estudos são sobre povos de língua jê e sobre Bororo, e o interesse por esses povos continua se manifestando na geração seguinte de antropólogos. Lux Vidal trabalha entre os Xikrin, Iara Ferraz trabalha entre os Gavião do Pará, Araci Lopes da Silva entre os Xavante, eu e depois Maria Elise Ladeira e Gilberto Azanha entre os Krahô. 
Os vários estudos sobre os Bororo, por exemplo de Renate Viertler e de Sylvia Caiuby Noaves, vêm de Thekla Hartmann, ou seja, de uma outra origem intelectual, mas não deixam de se interessar por um dos povos que mais impressionou Lévi-Strauss. Vários grandes grupos de povos que hoje estão muito mais estudados ficam um tanto de escanteio naquela época: os povos de língua pano, o complexo rio-negrino, o complexo xinguano, os Arawak em geral, os Guarani, e evidentemente os Tupi. Quando o Eduardo Viveiros de Castro faz a sua tese sobre os Araweté em 1984, o que ele está procurando é um contra-modelo aos grupos Jê, mas no espírito do Lévi-Strauss. Dessa vez não se trata de contestar Lévi-Strauss, trata-se de seguir essa mesma inspiração para grupos completamente diferentes. A primeira grande diferença que salta aos olhos é que nos grupos Jê a estrutura social está desenhada no chão, aquelas aldeias redondas com pátio central, com ou sem, dependendo da etnia, uma casa dos homens no meio: a estrutura social está representada topologicamente, e é uma pista, por vezes enganosa - afinal dualismo existe ou é um caso especial de triadismo? -, mas assim mesmo uma pista para se entender a estrutura tout court. Numa aldeia tupi não se acha nada disso, então onde está essa estrutura tupi? A estrutura jê, de certa forma, saltava aos olhos, nos Bororo talvez até ainda mais.

Os Bororo não são jê, mas são muito próximos culturalmente e foram um grande material para Lévi-Strauss. Nesse caso de primeira mão, embora a etnografia dele tivesse sido curta, ou seja, os Bororo tiveram uma grande influência no pensamento do Lévi-Strauss. Eduardo, quando organiza sua tese, que depois virou livro sobre os Araweté, toda a ambição é de pensar um modelo tupi completamente diferente do modelo jê. Ele se inspira em [Gilles] Deleuze e enfatiza a questão do devir, mas a inspiração está diretamente na linhagem de Lévi-Strauss. Vamos voltar atrás, vamos voltar a falar um pouco de Lévi-Strauss em vez da sua linhagem.

Algo que está aparecendo nas entrevistas para o filme $\mathrm{O}$ que Lévi-Strauss deve aos Ameríndios é esse avesso da proposta, que também é bem interessante, que é o que os ameríndios devem a Lévi-Strauss? Ao que me parece começa a haver um maior interesse dos antropólogos, nos grandes centros mundiais, para estudar os ameríndios.

Isso foi o que eu falei, não é? Franceses, ingleses, alguns americanos... Não há dúvida que há afinidades entre o pensamento indígena das baixas terras da América do Sul e o estruturalismo de Lévi-Strauss. Mas não basta dizer que Lévi-Strauss tem uma dívida com 
os índios, porque os índios têm também, por sua vez, uma dívida com Lévi-Strauss. Ele, ao interpretá-los, deu-lhes um renome e uma celebridade de que eles não gozavam desde o século XVI, desde Montaigne.

Podemos dizer que a partir de Lévi-Strauss isso seria a grande revolução? A partir dele se coloca os ameríndios em um debate antropológico mais amplo?

Exatamente, nisso você tem toda a razão. E o debate intelectual se coloca em outro nível.

Em outro nivel, não mais em uma etnografia que...

Também na etnografia, porque você não pode fazer teoria sem etnografia. Pelo contrário, é um estímulo constante a etnografia e a boa etnografia, nisso não há dúvida, você não pode fazer nenhuma teoria sem uma etnografia de qualidade. Pode ser de primeira mão ou de segunda mão como no caso do Lévi-Strauss. Lévi-Strauss faz pouca pesquisa de campo, mas conhece a fundo toda a etnografia da região.

A senhora mencionou o dualismo e aquela rixa acadêmica com David Maybury-Louis contestando o dualismo que Lévi-Strauss expõe. Segundo Anne-Cbristine Taylor, e o dualismo é um bom exemplo disso, os conceitos da antropologia estrutural têm seus fundamentos genealógicos no encontro de Lévi-Strauss com os indios. É nessa direção a proposta de dizer o que Lévi-Strauss deve aos ameríndios.

Eu acho que todo antropólogo deve às pessoas que ele tenta entender, porque o que ele está tentando fazer é traduzir uma coisa que é diferente e que ele tenta explicar. Então a dívida é enorme, agora o fato de Lévi-Strauss deixar os estudos de parentesco e estudar mitos também é uma coisa em grande parte por acaso. Porque ele é eleito para uma cátedra na École des Hautes Études en Sciences Sociales, se bem me lembro, de religião de povos sem escrita. Ele vai para os mitos, deixando os estudos de parentesco anteriores de lado. Esses acasos são importantes, se você se lembra da introdução que ele faz a $O$ Cru e o Cozido é muito interessante porque ele diz mais ou menos o seguinte: "estou passando de um material que é um estudo de parentesco para estudos dos mitos, no parentesco eu tentei mostrar as estruturas subjacentes, que eram as estruturas de trocas, generalizadas ou restritas", que ele faz no primeiro livro dele de 1949, As Estruturas Elementares do Parentesco. Quando ele passa para um material dos mitos, ele diz: "bom, aqui, se existe estrutura, 
ela não é uma estrutura prática, empírica, ela está em um plano mental, se eu acho estrutura aqui com muito mais razão isso prova que existem essas estruturas".

A senhora mencionou As estruturas elementares do parentesco e que em seguida ele comeca a se dedicar aos mitos. Pensando na obra de Lévi-Strauss, para alguns antropólogos a obra vai se "amerindianizando" conforme ele vai perdendo o foco nos universais, eu gostaria de ouvir a opinião da senhora com relação a isso.

O exemplo do dualismo serve muito bem para ilustrar isso. Há um lado de procura dos universais. Por um lado, ele está tentando entender o espírito humano e que ele postula, porque ele diz: "tanto faz se o pensamento ameríndio se realiza em mim ou se eu me expresso através do pensamento ameríndio" - isso também está na abertura de O Cru e o Cozido. Ou seja, ele diz algo como: “eu posso entender o que está 'rolando' nesses mitos porque eu sou um membro da espécie humana e como membro da espécie humana eu tenho a mesma estrutura mental profunda que qualquer outro ser humano, é por isso que eu posso penetrar e interpretar dessa maneira os mitos que eu estou interpretando. Eles estão se pensando em mim ou eu estou me pensando neles, tanto faz, é equivalente, porque compartilhamos, essa [estrutura mental profunda] sim universal, que é ser parte do gênero humano". A partir daí os universais desaparecem, não é isso que interessa a Lévi-Strauss. Quer dizer, o universal é de certa maneira a condição necessária para poder fazer o tipo de análise que ele faz. E a autoridade que ele reivindica é dupla, por um lado, é o fato de que ele é membro da espécie humana, por outro lado, essas análises só podem ser feitas com muita etnografia. É por isso que o conhecimento que ele tem, por exemplo, da etnoastronomia, da zoologia, tanto dos Bororo quanto de todas as outras etnias das quais ele fala, que vão depois até a América do Norte, isso é a matéria-prima dele, é com isso que ele trabalha. Isso é absolutamente fundamental, ou seja, em algum momento ele inclusive diz o seguinte: "não tenho nada a ver com a ideia, por exemplo, de arquétipo". Arquétipos em [Carl Gustav] Jung são universais: Jung afirma que algumas estruturas arquetípicas são comuns a toda humanidade, mas Lévi-Strauss nunca diz isso. A única coisa que é comum a toda a humanidade é uma certa maneira de organizar informação, o espírito humano, mas as estruturas são diferentes entre si, completamente diferentes entre si, não há nada universal nas estruturas, contrariamente ao que Jung pensa. Para Jung a ideia de sombra, a ideia de "anima", o "self", são estruturas que ele considera universais, que você olha para uma pintura tibetana, uma mandala tibetana e é capaz de perceber que ali é uma 
representação do “self”. Isso é absolutamente incompatível com um approach antropológico, que justamente privilegia as especificidades de cada sociedade, de cada tipo de pensamento. Você não pode interpretar diretamente, só através de uma etnografia exaustiva em que se tem que levar em conta como as pessoas entendem cada um daqueles elementos. Ele dá o exemplo sucinto e pedagógico em “A gesta de Asdiwal” [Lévi-Strauss, [1959]2013], que é um texto em que ele mostra como a ecologia, por exemplo, a subida e a descida dos salmões em certo momento naquela região do Canadá e do Noroeste dos EUA, como essa sazonalidade é usada para expressar uma estrutura. E aí entra o que eu chamei em um artigo que saiu em francês, o tipo de difusionismo de Lévi-Strauss. Quer dizer, essas estruturas são peculiares a cada sociedade, mas elas repercutem nas vizinhas, em geral por inversão. Elas não são como Jung quer, como uma coisa que simplesmente vai de um lado para outro e é interpretável por qualquer um. Nunca se pode prescindir da etnografia específica. Essa é uma das razões pelas quais ele fica com birra de Edmund Leach. Este último pretende aplicar o método do Lévi-Strauss à Bíblia, por exemplo, o "Nascimento Virgem" e "Lévi-Strauss no Jardim do Éden", são artigos do Leach em que ele prescinde completamente dessa coisa fundamental que é a etnografia específica. Quer dizer, a Bíblia, além de ter uma exegese que não acaba nunca, camadas e camadas de exegese, você não tem acesso à etnografia necessária. Por mais que haja arqueologia e filologia, você não tem acesso à etnografia que permita se fazer uma interpretação. O que Leach faz, ele [Lévi-Strauss] sempre recusou. Para ele o detalhe é fundamental. Lembre-se que, por exemplo, em O pensamento selvagem (1962), ele está dizendo que essas estruturas são formadas por coisas concretas, é a lógica do concreto, é o concreto que ele está procurando. Qual é o concreto que significa? Qual é o concreto significante para cada sociedade? Como é que cada sociedade organiza esse concreto? Mas se você não conhece o concreto, se não tem etnografia você não tem com o que trabalhar.

Eu acompanhei Lévi-Strauss numa visita que ele fez ao Brasil. Uma coisa que me chamou muito a atenção - ele estava fascinado pelo céu, dizia que o Brasil tem umas nuvens incríveis, um céu extremamente variado. Hércules Florence também dizia a mesma coisa (o pintor que fez parte da expedição do Rugendas). Lévi-Strauss ficava olhando para o alto e ficava olhando para as árvores e para os bichos e ele tinha um profundo conhecimento da etologia animal. Ele, além disso, era um cara que sempre defendeu os direitos dos animais e que sempre teve uma enorme sensibilidade não só ao concreto, mas a uma área animal, botânica, ecológica. O sensível é central para Lévi-Strauss. Dizer que ele é um intelectualista é perder sua grande originalidade. Você pode dizer que Jung era um 
intelectualista, não interessa se é adequado ou não, mas Lévi-Strauss certamente não. Lévi-Strauss era a pessoa que tinha a maior atenção possível ao sensível.

Sobre esse interesse dele por etologia animal, por botânica, etc. isso vem muito em função de entender as narrativas míticas e colocar essas narrativas míticas para debater com a ciência nesses âmbitos.

$\mathrm{Na}$ realidade, ele nunca faz uma apologia da superioridade do pensamento, do conhecimento ameríndio. Nunca ele o contrasta favoravelmente com a ciência. Ele tem o maior respeito pela ciência acadêmica, usa e se interessa pelos paradigmas dessa ciência, tanto que ele usa a Teoria da Informação logo muito cedo com [Claude] Shannon, ele usa Norbert Wiener, que estava muito em moda logo depois da Segunda Guerra Mundial. Ele está a par dos paradigmas de outras ciências contemporâneas dela, e investiga se são passíveis de serem transpostos à antropologia. Ele apregoa o que ele deve a linguística estrutural, ele fala muito da dívida dele com Jakobson. Tudo isso foram influências nos EUA, e também durante a Segunda Guerra Mundial, quando ele não pode vir para o Brasil e foi para os EUA. Felizmente ele foi salvo pela iniciativa do Rockfeller e lá ele está absolutamente a par dos últimos paradigmas científicos em outras ciências. Não é que ele está contrapondo a ciência indígena a uma ciência acadêmica, ele está mostrando que o funcionamento é semelhante. Ele faz um contraste n'O pensamento selvagem em que ele diz: "acontece que esse pensamento parte do percepto, da coisa sensível, daquilo que é percebido, ao passo que a ciência parte do conceito e isso dá uma diferença brutal quanto aos resultados". O fato de partir do conceito, o que a ciência faz, dá resultados que ele aprecia. O que ele está dizendo é que o pensamento selvagem pode não operar no nível do conceito, e sim no nível do sensível, mas que as operações são as mesmas. Não há um pensamento pré-lógico, não há um pensamento diferente entre sociedades diferentes. O que há é a matéria-prima ou ponto de partida que é diferente. Com a ciência, como ele diz, o fato de partir do conceito faz uma enorme diferença. Ele não faz a apologia da ciência indígena, ele faz apologia da mente indígena, o que é bem diferente.

Podemos pensar que se Lévi-Strauss fižesse o mesmo trabalho que ele fez com os ameríndios, pegando mitologias de outro lugar do planeta ele chegaria então aos mesmos resultados?

Não, não chegaria porque ele não se atém ao universal, eu repito. $\mathrm{O}$ que ele mostra é o pensamento ameríndio. Como organiza o mundo, como se organiza esse pensamento 
ameríndio, e há continuidades no continente. Continuidades e, sobretudo descontinuidades, mas que falam umas com as outras. Há diferenças entre os vizinhos. São diferenças que fazem parte de um sistema. Para ele a estrutura não é uma estrutura, não se dá em um exemplo, é um conjunto que, de certa forma, cada elemento responde aos outros. A estrutura é um conjunto de instanciamentos, de realizações diferentes desse modelo. A estrutura na realidade é um conjunto de transformações, mas específica para cada região, por exemplo ameríndia. Essa estrutura é específica, o pensamento humano é universal. Se ele estivesse na Ásia do Sudeste ou no Japão ele encontraria outras estruturas.

No grande epílogo das mitológicas, que é História de Lince, ele mostra que esta estrutura ameríndia é totalmente diferente e oposta à estrutura tripartite indo-europeia.

E isso é influência do [Georges] Dumézil. Aí tem um ponto interessante: ele foi influenciado por Dumézil, que é o inventor da ideia de uma estrutura tripartite indo-europeia. Ele tinha lido o Dumézil e sofreu influência dele. Acho que aí houve provavelmente uma semente: "se isso é uma estrutura indo-europeia será que existe uma estrutura ameríndia?’. Creio que houve uma influência. Agora, o método dele e o método do Dumézil são completamente diferentes.

Podemos dizer que existe uma influência recipproca entre Lévi-Strauss e os estudos sobre os indígenas?

Eu acho que há uma influência recíproca, acho que é uma coisa importante de se entender, mas não se deve reduzir tudo a isso, porque há um paradigma importantíssimo que é o da linguística estrutural, há a questão da teoria da Cibernética do Norbert Wiener, que é importante para ele etc. Há, não sei se você conhece o artigo do meu marido [Mauro Almeida, 1990] sobre os modelos matemáticos em Lévi-Strauss, e lá ele assinala influências que não são conhecidas, justamente a da Cibernética a da Teoria da Informação em Lévi-Strauss. São modelos com os quais ele dialoga e que o inspiram, muitas vezes. Mas o inspiram de uma forma muito original. O fato de ele estar sempre lendo as revistas Science, Nature, tem a ver com esse diálogo com os paradigmas das ciências duras. Há um diálogo teórico importante em Lévi-Strauss que está também numa relação dialética com o pensamento ameríndio. Ele está usando esses instrumentos para tentar entender esse pensamento ameríndio. Agora, pensar que Lévi-Strauss vem de um pensamento ameríndio, não. Ele foi capaz de explicitar esse pensamento ameríndio com a sensibilidade que ele 
tinha para o que ele estava lendo, esses mitos todos, e percebendo as conotações desses personagens, mas imbuído, ao mesmo tempo, de uma certa maneira de organizar esse material. Fazer aflorar essas estruturas não é trivial e pode muito bem ser que os próprios ameríndios não se reconheçam nisso. Isso é uma coisa interessante porque torna a teoria estruturalista uma teoria que, nos termos de Karl Popper não seria cientifica. Para Karl Popper é cientifica uma teoria que permite chegar a um experimento que a infirme, que a negue, que dê errado, um experimento em que sua expectativa seja $X$ e não sai o $X$. Claro está que essa é uma versão positivista e já ultrapassada de que uma teoria científica seria aquela que pode ser infirmada empiricamente. No caso de Lévi-Strauss, as interpretações que ele dá não podem ser infirmadas porque mesmo o fato de chegar um Bororo e não reconhecer a análise do mito de origem do fogo que Lévi-Strauss oferece não infirma essa análise. Agora o que pode infirmar, sim, é uma melhor etnografia, ou seja, se aqueles personagens que são associados por Lévi-Strauss através da bibliografia que ele tinha, que ele dispunha, não têm na realidade essas conotações. O Bororo que contestar a análise do mito de origem do fogo não tem necessariamente a última palavra. Porque, em geral, a gente não tem consciência das estruturas. Da mesma maneira que a gente não tem consciência da gramática quando a gente está falando. A gente vai falando e usando a gramática, mas sem ter necessariamente consciência das regras que está usando, sobretudo na sua própria língua, ou seja, essa estrutura não é necessariamente consciente. Pode aflorar à consciência, mas não é necessariamente consciente e não há um privilégio para a interpretação, para dizer "não, essa análise está errada". Não há o privilégio do membro dessa sociedade. O privilégio do membro da sociedade é corrigir a etnografia, isso sim, e a partir de aí dizer "bom, isso aqui está mal interpretado", mas não porque ele detenha uma maior consciência das suas regras gramaticais. É isso, basicamente.

Um Bororo não poderia infirmar justamente porque as Mitológicas são mais uma versão da mitologia ameríndia.

Quem é que detém, por exemplo, a verdadeira interpretação da Bíblia? Tem muita competição por isso, gerações e gerações de exegese. E quem tem razão? Se um patriarca bíblico aparecesse e dissesse "não tem nada disso aqui", ele teria mais autoridade? Não sei, entendeu? Como diz Lévi-Strauss, é mais uma versão. Mas o que está em jogo na realidade é muito mais perceber que existe uma lógica poderosa em atuação que é mais interessante 
que ter certeza de que essa é a interpretação correta, porque sempre vai ter mais e mais camadas de exegese.

Gostaria agora de mudar um pouco o foco das questões. Hoje, como a senhora sabe, há cada vez. um número maior de indigenas na universidade e muitos fazendo curso de antropologia e se interessando muito por antropologia. Eu queria um comentário seu sobre isso e sobre esse possivel encontro dos indígenas com Lévi-Strauss, o que a gente pode esperar disso. Eduardo Viveiros de Castro diz que a obra de Lévi-Strauss projeta uma "filosofia por vir" (2008). A senhora comentou sobre um dia um Krahô lendo Lévi-Strauss, seria possivel antever alguma coisa da opinião dele? Quais as expectativas dessa leitura?

Eu acho que quem está fazendo com muito sucesso essa transformação do pensamento ameríndio em filosofia é o Eduardo. É ele que está conseguindo mostrar que existe um paradigma que é totalmente anti-intuitivo para a tradição ocidental. Eduardo é quem está mostrando que para os ameríndios há várias naturezas, mas uma só cultura, e que isso é o inverso do que se pensa no Ocidente, que a natureza é uma só e que a cultura é múltipla. Esta é uma asserção filosófica e esse é o poder dessa filosofia indígena que o Eduardo está conseguindo colocar em evidência, transmutar, do pensamento indígena até uma filosofia propriamente indígena. Eu acho que não são necessariamente os acadêmicos indígenas que vão explorar isso. Eles vão, provavelmente, em direções que a gente nem imagina. Certamente eles vão fazer muitas críticas à antropologia. Eles já estão fazendo, de certa forma, uma interrogação: "por que os antropólogos são sempre estrangeiros?". Eles vão, com certeza, reivindicar um papel central na interpretação das suas próprias sociedades. Eu acho isso muito legal. Apesar do famoso distanciamento que se exige para a gente conseguir entender e interpretar sua própria sociedade. No entanto, e talvez eu me engane, eu não vejo que seja o papel deles de, de repente, trazer uma nova filosofia para a arena das ideias. Pode ser, não sei. Eu estou curiosa para ver. O verdadeiro risco é que eles não contestem as ideias vigentes, só exijam serem eles que as proclamem.

É um pouco como a situação de índios que aspiram a se tornar padres. Ficam em posição de autoridade, mas à custa de endossarem uma cosmologia alheia. Os índios antropólogos podem se tornar "autoridades", mas à custa de endossarem a antropologia existente.

Quem realmente renova é uma figura como David Yanomami, com a colaboração preciosa de Bruce Albert: renova porque David consegue falar de seu próprio ponto de 
vista e que Bruce Albert é capaz de traduzi-lo para os do lado de cá. Considero que o livro A queda do Céu (2015), desses dois autores, é uma obra-prima, um dos livros mais importantes deste século.

Há dois tipos de coisas que estão ocorrendo: por um lado há muito mais estudantes indígenas nas universidades, isso é ótimo, excelente, e, por outro lado, existem vários cursos para professores indígenas, que são coisas completamente diferentes entre si. Esses cursos para professores indígenas são os que vão voltar para as aldeias e vão ensinar, entre outras coisas, cultura indígena. Há problemas nisso já de saída, porque cultura indígena se aprende fora da sala de aula, se aprende em casa, por assim dizer, ou nas atividades, na prática. Também não se trata de preservar simplesmente via a escola os chamados "conteúdos culturais", e sabotar assim as regras de transmissão de conhecimentos dos povos indígenas. Há vários paradoxos que têm que ser pensados. Não sei se são passíveis de serem resolvidos, mas certamente têm de ser pensados. Me parece que, sem dúvida, é fundamental o incentivo às línguas indígenas - estou falando da formação dos professores indígenas - sem dúvida é fundamental que eles conheçam os mecanismos que eles têm de defesa jurídica, dos direitos que têm, enfim, de uma série de coisas que, aí sim, se aprendem fora e que devem ser interiorizadas. Agora, quanto aos indígenas que estão nas universidades em outros cursos, o grande medo das lideranças indígenas é que eles não voltem ou que eles não se preocupem em beneficiar as sociedades das quais eles vêm. O fato é que para muitos estudar é uma via de saída da sua sociedade. Isso um líder ashaninka me explicou muito claramente, quando disse: "a gente indica uma pessoa para ir fazer curso superior e essas pessoas muitas vezes não voltam nunca mais, então a gente não quer que isso seja uma saída, a gente quer que seja um reforço, que voltem”. Um advogado indígena tem que ser muito bem formado e informado dos problemas que existem na sociedade dele, para poder ter uma atuação adequada. Não quer dizer que ele precise morar, mas ele precisa guardar os laços com a sociedade de origem e não é isso que sempre acontece. Isso é uma preocupação que tem que ser pensada, como fazer com que isso não seja a nova colonização, a nova "missionarização" das sociedades indígenas. Porque a escola é um perigo, é um perigo mesmo. A escolarização tem hoje um valor muito grande. Por exemplo, lá no Rio Negro [AM] todo mundo quer que os filhos tenham diplomas e fazem enormes sacrifícios para isso, se mudam do seu sítio e vão passar fome na cidade para seus filhos estudarem e o resultado é muito parco. O sistema escolar para indígenas, que não se confunde com o sistema de formação indígena e é uma política cultural que tem enormes riscos. 
Esse paradoxo que a senhora está mostrando é bastante pertinente. Porque é uma demanda indígena, eles querem escolarização do "branco", na maioria das vežes, e ao mesmo tempo querem manter sua lingua, sua cultura.

Tudo bem, a língua é fundamental, mas não é tudo. O ensino que se dá na maioria das comunidades indígenas desvaloriza completamente o conhecimento tradicional, separa-se desse conhecimento tradicional, faz-se uma barreira entre o que a criança aprende em casa e o que ela aprende na escola. Isso não só separa esses dois universos, mas desvaloriza tudo o que se aprendeu de importante em casa. As mães não levam os filhos para a roça porque eles têm que estar na escola naquele mesmo horário. Quer dizer, há uma erosão do conhecimento tradicional que, às vezes até com muito boa fé se dá, mas que é extremamente problemático. Se eu começo a falar disso, nós vamos longe.

Você passou por uma experiência assim no Acre, de criação de uma universidade indígena. Como foi esta experiência?

Bom, aquela experiência foi um desastre, porque foi encampada por uma universidade que tem protocolos que são incompatíveis com a possibilidade de se manter ao mesmo tempo um conhecimento indígena e se dominarem outras técnicas e outros paradigmas também. O modelo de universidade com os seus concursos, com toda sua organização é muito dificilmente compatível com conhecimentos indígenas. É bom que haja uma universidade federal em Cruzeiro do Sul, mas ela não é diferente de todas as outras. Atualmente está em gestação uma experiência que pode vir a ser original, um instituto de conhecimentos indígenas no Alto Rio Negro, que tem boas perspectivas de vir a se concretizar. Eu mesma fui encarregada pelo Ministério de Ciência, Tecnologia e Inovação de tentar estabelecer as bases para um programa de diálogo entre o conhecimento tradicional e o conhecimento científico. Isso é uma coisa que está começando, vai demorar, mas a ideia é chegar a um programa mais permanente. Esse instituto de conhecimentos tradicionais seria no Rio Negro, porque há toda uma organização forte dos índios e muitas pesquisas ditas interculturais já foram realizadas lá, particularmente pelo Instituto Socioambiental [ISA]. Existe a possibilidade de uma coisa realmente inovadora lá. 
${ }^{1}$ Pós-doutorando pela Universidade de São Paulo.

${ }^{2}$ Este filme pode ser assistido no seguinte site: http://www.vimeo.com/lisausp/levi-strauss

\section{Referências bibliográficas}

Almeida, Mauro W. B. de

1999 Simetria e entropia: sobre a noção de estrutura de Lévi-Strauss. Revista de Antropologia [online], vol. 42, n.1-2: 163-197.

CARneiro da CunHA, Manuela e Almeida, Mauro. W. B._(orgs.)

2002 Enciclopédia da Floresta: O Alto Juruá. Práticas e Conhecimentos das Populações. 1. ed. São Paulo, Companhia das Letras, v. 1.

CARneiro da CUnHA, Manuela

1973 Logique du mythe et de l'action. Le mouvement messianique canela de 1963, L'Homme, vol. 13, n. 4: 5-37.

2010 Conversa com Manuela Carneiro da Cunha. In Cultura com aspas e outros ensaios. São Paulo, Cosac Naify.

KopenAwA, Davi e Albert, Bruce

2015 A Queda do Céu - Palavras de um xamã yanomami. São Paulo, Companhia das Letras.

LÉvi-STRAuss, Claude

[1949]1976 As Estruturas Elementares do Parentesco. Petrópolis, Vozes; São Paulo, Edusp.

[1959]2013 A gesta de Asdiwal. In Antropologia estrutural II. São Paulo, Cosac Naify. 1996 As Organizações Dualistas Existem?. In Antropologia Estrutural. Rio de Janeiro, Tempo Brasileiro, pp. 155-192.

LOYER, Emmanuelle

2015 Lévi-Strauss. Flammarion, Grandes biographies, 910 pp.

MAYBURY-LeWIS, David (ed.)

1971 Dialectical Societies: The Gê and Bororo of Central Brazil. Cambridge, Mass., Harvard University Press. 
Nimuendaju, Curt

1946 The Eastern Timbira. University of California Publications in American Archaeology and Ethnology, Vol. 41, Berkeley e Los Angeles, University of California Press.

Viveiros DE CASTRO, Eduardo

2008 Claude Lévi-Strauss, fundador del posestructuralismo. Conferencia presentada en el Coloquio Lévi-Strauss: un siglo de reflexión. Museo Nacional de Antropología, México, 19 de noviembre de 2008. 